\title{
The Relationships in Novels from the Perspective of Literary Ethics-Taking the Film Lolita as an Example
}

\author{
Zhaodong Zeng \\ School of Foreign Languages, Shanxi Normal University, Linfen, 041000, China
}

\begin{abstract}
Vladimir Vladimirovich Nabokov is an outstanding and productive Russian-Amercian writer. As the epitome work of the writer, Lolita must be the most controversial novel without doubt. This novel has been adapted into two versions of films: 1962 version and 1997 version. This paper will analyze the 1997 version of Lolita directed by Adrian Lyne. Most critics have mainly conducted the analysis of the film form the perspective of ethnics, postmodernism, narrative strategy, time as well as the image of death. However, there are few, if any, researches done from the perspective of literary ethics to dig into the relationships in the film. With the integration of ethics methods and literary research methods, literary ethics serves as a major new criticism approach and is mainly employed to conduct the analysis of literature. With the ethical factors unveiled in Lolita, this paper seeks to analyze three relationships: human beings and society, human beings and self, ethics and truth. The paper interprets the film Lolita from the perspective of literary ethics, explores the relationships in the film, exploits Vladimir Vladimirovich Nabokov's pursuit of truth, kindness and beauty, and also hopes to provide a new direction for later research on the film Lolita.
\end{abstract}

Index Terms — Lolita, literary ethics, human-society, human-self, ethics-truth

\section{INTRODUCTION}

Few literary characters have gone out of the original work to become a cultural symbol, and "Lolita" is such a cultural fit. The first sentence of Vladimir Nabokov s novel begins like this: "Lolita, the light of my life, the fire I want to read, my sin, my soul". Rational people might say that a middle-aged uncle's obsession with a 12-year-old girl is abnormal. The sensuous man might say two rootless vagrants come together, they are only victims of the times, and there is a living case of facts at that time. The controversy of this novel is to describe Humbert's obsession with and love for the young girl Lolita from the perspective of the violator, who writes the innocence and ignorance of Lolita girls as a temptation to himself. It is not a third-party description of documentary writing, but rather Humbert's self-defense of his paedophilia. Therefore, it angered the conservative religious society of the time. But a world-recognized book of wonders needs to describe the moral criticism of the character's heart, and make readers think with lost words, dreamy scenes, and extreme stories: He used Lolita to criticize every aspect of American social life. Lolita's original film has two versions of films. One is a black and white film directed by Stanley Kubrick in 1962. Kubrick bought the copyright of the novel for 1.5 million dollars at that time, and because of the strong "Hans Code" system at that time, the film used black and white film, also did not make an article on the scale, but highlighted the original work joke, the satirical part, added to the film's suspense, became a black humorous masterpiece (Wang Jianping, 2006). In general, "Lolita", a literary work that reflects humanity with its unique vision, has become a kind of "symbol" that explores the transformation of human nature and the anti-tradition in the study of historical literature. But it reveals, in some ways, something naked and unavoidable in human nature: desire and moral rebellion. This article will closely adhere to the concept of literary ethics and the perspective of research, take the film version of Lolita as the model of study, try to explore the true connotation of the film and the enlightenment and breakthrough to the study of ethical novels. The most important thing is to probe into the feudal era under the rule of American ethics and religion through the systematic analysis of the character image, what kind of impact this kind of literature film and television will bring to the society, what kind of influence it will bring to the test of human nature. This is the core purpose of thesis writing.

\section{THEORETICAL BASIS AND LiterATURE REVIEW}

\section{A. Theoretical Basis}

Western literary ethics has come into a second life from 1980s to the early 21st century and oriented towards literary ethics criticism. The researches on literary ethics which have been conducted in the end of the twentieth and twenty-first century suggest that literary ethics has been unlocked from Formalistic Approaches, Structuralist criticism, psychoanalysis, feminist criticism and cultural criticism and thus achieved the ethical coming back of literary criticism. Beyond that, literary ethics has set a paradigm and fostered a brand new criticism hit. However, as Richard a Posner 
says, "literary ethics criticism is just a broad concept in western society" (Richard A Posner, 1998).

Literary ethics is still a relatively broad concept. An excellent literary ethics mainly includes criticizing or analyzing the corresponding behavior or ideology based on certain social moral norms. Half of literary ethics will involve human relations, social moral concepts, and more importantly, many literary ethics will involve pornography and sex. Integrated with literature, art theory, ethical theories, philosophical ideas and sociology, the subject of literary ethics has emerged in a natural way. Since it was put forward, literary ethics criticism has been paid more and more attention by scholars on the basis of the uniqueness of its critical perspective and the originality of its critical methods. Literary criticism method, which has been reconstructed and improved based on painting lessons from western ethical criticism and Chinese moral criticism, provides a possibility for fully understanding the complexity of literature and interpreting literature from a new point of view. Booth realized that the term "ethics" tends to be easily misunderstood as a kind of criticism based on some ethical standard. In his opinion, ethical judgement is just a small part of ethical criticism (Wayne C. Booth, 1988).

John Schad believes that ethical criticism should be thought as a matrix, a center of mutual exchange of various terms and rhetoric, sources of disciplines and convergence with itself (John Schad, 1992). Therefore, as literary ethical criticism develops and improves its theoretical construction, it is also necessary to integrate with the criticism methods and literature of psychology, history, religion and other disciplines. That means to further construct an inclusive and comprehensive foundation for ethical criticism theory. Some scholars believe that in order to make a breakthrough in the future development of literary ethics criticism, the accurate grasp of the current social ethics connotation should not be ignored. Nie Zhenzhao partly has learned from the ethical literary criticism theory and believes that the process of human's evolution from ape to man is the first choice that humankind has ever made in the long history, namely, the Darwin's natural selection (Nie Zhenzhao, 2011). It can solve the problem of the source of the human beings but that people get the essence of man is implemented by the ethical choice from birth to death. Life is made up of individual ethical choices, and we are living in the ethical choice which is evolved through natural selection. Because of the rapid development and drastic changes of contemporary society, the concept of human ethics is bound to change greatly, and then the connotation of literary ethics criticism is different from that of traditional ethics criticism. As far as western literary ethics is concerned, it mainly refers to most of the Chinese literary criticism over the past 100 years, especially over half a century, comes from the west. Nie Zhenzhao has made a summary of some necessary parts in literary ethics criticism, including the relationship between writers and the writing, the works, the relationship between writers and their works. As for works, they should analyze and research the correlation between literary works and all types of ethical phenomenon in real society the works exhibit. That means how literary works mirror ethical and moral phenomenon in actual life through exhibiting a virtual world. Besides, they should also study the ethical trend reflected in literary outputs and literature's values on society and ethics (Nie Zhenzhao, 2004).

\section{B. Literature Review}

Criticism methods featured prominently in literary theory of the twentieth century in the western countries, which was mainly reflected by a constantly increasing number of criticism theories and continued development to this day, which contributed to what many scholars called "the century of literary theory". Since the beginning of modern times, Chinese literary researchers, including those who are engaged in literary criticism and literary theory, have adopted western critical methods, and ethics is not meta-ethics. The difference is that meta-ethics studies "what ethics is" and provides metaphysical presupposition for ethics. Ethics is actually "ethicist ethics", which is the basis of ethical norms to be obeyed by ethicists, and western ethics has a very strong religious flavor. The origin of western ethics can be traced back to the rhetoric ethics of ancient Rome and ancient Greece, which covers the theories of Whitley, Compabail, Socrates, Plato, Aristotle and so on.

There are many achievements in the study of communication ethics, which are recognized as some famous theories of the absolute moral spirit in the West. Romane Clark has put forward four points of importance and reasons for the moral functions and educational functions of literature. Firstly, it centers on people's soul and the development of standardization; secondly, ethical emotions produce need for religion; thirdly, religious belief is beneficial to the formation of positive ethical emotions and thus develops into one of tools for ethical education; fourthly, the importance of religion cannot be ignored and historical education should be strengthened (Romane Clark, 1988). Examples include Kant's absolute orders, Rawls's admiration for ignorance, Aristotle's middle principles and Mill's principle of maximum happiness. The literary ethics used in the thesis is a universal critical theory of literature in China and the West, and is explored from the perspectives of human nature, social responsibility and literature in pursuit of life and art.

\section{THE INTRODUCTION OF THE FILM}

The film Lolita that is adapted from the novel written by Nabokov, a famous Russian-American writer, has been prohibited from publishing for many years because it tells stories about unruly love between Lolita and Humbert in the book, which was not allowed by American morality. But as time went by, people began to realize the amazing beauty of the works and the exquisite beyond the times, which made her rediscovered again and again. As an erotic film, Lolita, especially Adrian Lynn, director of the 1997 edition of the film, fully grasps the American characteristics of openness and stubbornness on the one hand, and strives to pursue the ultimate expressionist aesthetics in the atmosphere, emotion, 
form and means of erotic expression, thus making the film a success.

It's hard to forget that 14-year-old Lolita was lying on the lawn. It is beautiful, but also full of temptation, misty sunshine and mist, green garden, let Lolita appear as a scene full of poetic beauty. The protagonist, Humbert, a European immigrant who has received higher education but has acted beyond the scope of morality, falls in love with a lovely but dangerous and ruthless adolescent girl and begins a crazy love affair. Nabokov breaks through the fixed expression patterns of sex, morality and aesthetics, and combines the structure and narrative language of the film to form a mischievous fantasy. The script retains the wisdom and poetic language of the novel, but considering the limitation of large screen presentation, the story is quite different from the novel. It will be an exciting and satisfying reading experience for readers.

\section{THE INTERPRETATION OF RELATIONSHIPS IN LOLITA}

\section{A. The Detached Relationship between Humbert and Society}

Ethic is broader and wider in terms of area and field and represents the issue of how people live, while morality is more specific, mainly refers to the rights and obligations of people have as individuals in society and is a choice between right and wrong. In the film, when Humbert gradually dropped into the love and sexual desire and wanted to take the possession of Lolita, he came to realize one important ethical issue, that is, Charlotte was the obstacle between him and Lolita and the best way to solve this problem is to let Charlotte vanish. But Humbert did not turn his ideas into practice because he knew that was crime and just played the scheme in his mind, only a kind of "imagining crime". However, to his surprise, Charlotte accidentally found his diary and thus knew all of his secrets. After that, Charlotte cried and rushed out of her house, dying of traffic accident. This is an important turning point and a tricky design (Wang Zhuo, 2015). The combination of Humbert and Charlotte leads to the ethical relationship between him and Lolita. The accident that happened to Charlotte means all the obstacles have been cleared out, making it possible for Humbert to be with Lolita and not to practice his "imagining crime" and be accountable for legal responsibility and ethical criticism.

In general logic, now that all the obstructions have been dispersed, Humbert should have expected an exciting prospect and enjoy endless pleasure, but the truth is not like that (Nie Zhenzhao,2 010). New ethical confusion and fear floods him: how could he define the relationship between him and Lolita? Although he can get rid of the stepfather-daughter relationship with Lolita, he cannot be with Lolita naturally. As far as social civilization and ethical environment of the time are concerned, it is abnormal to purpose to a girl who is only 12 years old and unacceptable in the whole society. For this, Humbert even looked up relevant legal regulations and books to look for some possibilities for him to marry Lolita. On the way to leave their home, Humbert tried to let Lolita sleep with the use of hypnotics to appreciate the beauty of the girl closely. Back then Humbert did not have the lust to possess her. Humbert sexually desires for Lolita not in a general meaning but out of a pursuit for illusionary beauty and obsession with the lust. Like some critics said, "the old Europe raped the young America" or "the young America lured the old Europe", anyway, Humbert took the first brave step and broke the traditional ethical taboo, starting an abnormal love with Lolita.

Humankind has become the core and center of the literary writing since the term literature was created. A great number of writers have described and explored realistic and poetical human nature in order to exhibit and dig into people's different backgrounds of their living and their internal world in the depth. What is more, it is obvious that nobody lives in an isolated way and all people belong to and reside in a certain community (Liu Jie, 2012). And writers cannot immune them from describing various relationships between people and the community where they belong if they want to embark on literary works. Hence the connection between humankind and the society naturally turns into the main relationship in literary description. Besides, criticism as well comments on the relationship between human and the society so as to mirror the significant and prominent role of humankind. As a result, as Professor Li Dingqing says, literature play as a minor of social life and strives to show realistic life and disclose important values and profound meaning in life (Li Dingqing, 2006). The film shows its audience a clear map of how people live and what ideal and spiritual state they are into in America which has gone through the disaster the Second War caused. Nabokov described American family, marriage as well sexual conditions. And the family relationships among Lolita and her family as well as Humbert and his family. Humbert got married out of some kind of promise instead of due to true love, and his sexual education which should have been given by his parents is lost. No matter in whose family life, there are so many absent things such as marriage and sexual education.

The film vividly depicts American people's survival and psychological condition after the Second World War. Relationships within a family play a significant part in the relationship between people and society as well as children's growing up. Humbert, the leading character, is blessed with solid financial basis and glorious fame, but he loses his mother when he is three years old while his father is buried in his work and busy with social activities without showing any care and love about his son. This lousy and miserable childhood finally has a profound and significant influence on Humbert's whole life. The life of Lolita, another protagonist in the film, is also painful as her family is not harmonious and unpleasing. Lolita loses her father and her mother does not care about her so much or even is harsh on her with regard to her mother's attitudes. Her mother's strictness and impatience triggers Lolita's revolt. Besides that, Lolita is also influenced by her mother's lust for luxuries and extravagant lifestyles in terms of her aesthetic standard.

Neither Humbert nor Lolita is warmed and cared about by their respective families. This kind of unhealthy and disharmonious family relations leads to abnormal social relations. At the end of the film, Lolita becomes a mother of her 
own child and tries her best to give enough care and love as she can to her baby, which exactly reflects the humanity sentiments. As Martha $\mathrm{C}$ points out, values judgement in the course of ethical criticism has the features of complexity and multidimension, which is similar to the process of selecting an item with the quality as the standard. Each item has its own distinctive value no matter which one is selected (Nussbaum M C, 1990). Their so-called abnormal love cannot be easily judged with regard to their family background.

\section{B. The Relationship between Humbert and Self}

As Lolita grew up, Lolita started to get tired of their vagabondage and their abnormal relationship, so she secretly saved money and schemed to escape. Humbert was too dependent on Lolita as he was accused by ethical criticism. Therefore, Lolita escaping was such a hit to him and took away all of his security sense. He then began to search for her insanely and lived a wandering life. He received a help letter from Lolita three years later when she was a married woman and pined away and no longer was a beauty as before. Meanwhile, he knew that she was lured by the indecent playwright Quilty and forced to shoot porn movies. And after Quilty fooled Lolita, she was married to a reliable man named Dick and lived a miserable life. Knowing all of the story, Humbert was filled with mixed feelings and had no idea which identity he should use to meet Lolita, stepfather or lover. The ethical dilemma made him painful and ashamed. He wanted to kill Dick but did not do it because he believed that Dick was capable to give Lolita a normal and happy life. He was not jealous but gave a lot of wealth to Lolita. At the time, Humbert showed up as her stepfather and delivered the duties of a father. He hoped to help Lolita and wished that Lolita could live a happy life.

Later Humbert found Quilty and shot him and now, Humbert played the role of lover and the one he killed was his rival in love. Having killed Quilty, Humbert felt comfortable and easy. That was because he finally got rid of the ethical dilemma which had bothered him for a long time and did not have to suffer from the torture and pain. Quilty appeared in the film as a mysterious image and until the end of the film his identity was disclosed. Actually, Quilty was another Humbert, the mirroring image of dark and degenerated, which was demonstrated in the fact that Humbert always regarded Quilty as the rival of the same power. That meant Quilty was the incarnation of dark Humbert, the one who had sex with Lolita and escaped the reality, the soul which suffered from ethical confusion and moral fear. In fact, what the Humbert killed was the evil side, the dark side and the side which he hated. The murder represented the final rational verdict and the ultimate trial, which was why Humbert chose to let Quilty announce the death warrant. Humbert's ethical awareness and situation at the beginning of the story indicated his ruin.

It is most intrinsic and difficult to probe into, among all types of relationships, the one between human and the internal world, that is to say, the one between a man and himself. Of all the functions of literature, one capacity is to discover what human's nature is and what their inner world is like. There are chances for literature to disclose and dig into how deep and wide the human nature is, as an individual is closely associated with his inner world instead of being isolated from each other. One of aims of ethical literary criticism is to expound and interpret the intrinsic and hidden values expressed in one certain literary work. Since human existed on earth and came to be true humankind differentiated from animals, the final task has been to probe into the relationship between human and self. Over three millenniums ago, humankind cast concerns about himself and got the desire to truly know the internal world and dive into the nature of himself.

As the exploration of the relationship between people and self is focused on the character Humbert, the film actually tells that Humbert's aspiration is the reflection of his desire for love and spirit dependence. First, he is a boy who has a miserable and painful experience and the truth that his first girlfriend and mother pass away has caused profound influence on him. In his childhood when he does not get enough love and care from his mother resulting from his mother's early death and form his father, Humbert hopes that he can get love from his first girlfriend Annabel to make up for what he has not got form his mother. When Annabel dies, Humbert tries to obtain the similar love of other girls to the love of Annabel as a way to have another chance to console himself and fix the broken heart. This emotional development is an important reason for his being a pedophile.

In Humbert's eyes, Lolita is the replacement of Annabel and wants Lolita to be his sexy girl forever. At last, Humbert strives to look for Lolita after she leaves. But what he has chased after is actually not Lolita, instead, the unforgettable and happy memories he has spent with Lolita are the prey. Just like Annabel, Lolita leaves, too. At the moment, Humbert comes to realize that the past time cannot be found and reached no matter how hard he tries.

Humbert is most likely to be a normal social person when he is with Lolita. But when he receives the letter form Lolita, he determines to leave Lolita, which marks his spiritual aspiration is deemed to be a failure. The end of the film mainly talks about the Humbert's self-confession. And what he fails is that he ruins one girl's life. The shift from a miserable boy through a pedophile to a normal social person of self-confession turns his sexual love into real love for Lolita. The final guilty and confession of Humbert is the core of the film and the reflection of the original writer's humanity.

\section{The Relationship between Ethics and Truth}

The task of ethical criticism is not to comment on whether the story breaks the moral rules or not but to analyze the profound influence of the story on readers' quality, emotions and values. Humbert was a poet full of illusion before fornication came to his mind and kept searching for sexy girls like Annabel to fill his desire. He was in normal relationships with social women but felt depresses and painful instead of satisfied and happy. He harbored strong desire 
for every sexy girl and was close to be insane. But he did not do anything evil and illegal as he already was clearly aware of ethical issues and knew it was not allowed to have sex with girls. He was ashamed and guilty, and later he got married in order to get away from the pain and fear brought about by unethical thoughts. At that time, he hoped to transform his ethical ideas by resorting to the external environment and internal introspection as a way to get back to the normal social order, which reflects the struggle between his self-control and. Literary ethics believes that "the Sphinx factor consists of two parts: human factor and beast factor". These two factors are organically integrated and the human factor is the high-level factor while the beast factor the low-level factor. But the former can control the latter and thus make human beings have ethical awareness (Nie Zhenzhao, 2011).

Humbert completely turned his illusion into Lolita from Annabel until he met Lolita and gradually fell into the abyss of ethical taboos and lost the power of escaping. In order to get Lolita and stay with her for the rest of his life, Humbert decided to marry Charlotte and then naturally become the father of Lolita. In later life, Humbert paid close attention to every move and smile of Lolita and appreciated her charming and tempting body. Beyond that, he did a series of petty action like often showing tender care for her and hugging her. New happiness was full of his heart and mind but he also felt miserable, so he had to take control of and suppress the sexual desires deep into his heart so as to secure the 12-year-old girl's purity. As an adult of ethical awareness, Humbert knew his thoughts were immoral and filthy as well as unacceptable to the whole society. Therefore, he kept self-introspecting and tried to fight against his emotions with reason. He was afraid that the beast factor would ultimately beat the human factor if he let the ideas be. Therefore, Humbert is twined by ethical confusion and fear and dropped into an ethical trap that he could not escape from. As a modern knowledgeable professor, Humbert was sober-minded about what the outcome could be in the future be he the slave of his desire. The conflict between individual life nature and social orders was getting more and more incompatible and the struggle with ethical awareness was becoming more and more fierce. The story would step into an irreversible result.

The interpretation of Lolita as a "moral novel" is controversial: judging Lolita from a moral point of view may fundamentally misread Nabokov's intention to write. For Nabokov-style writers, readers who hold such views argue that "the purpose of literature and art is literature and art itself, and its existence is for beauty. The "literariness", "aesthetic consciousness" of the novel and the criticism of the novel as moral preaching form the inner clue of their argumentation. If the moral interpretation of Lolita is included in the context of the traditional text, then the highly respected "aesthetic consciousness" is often in conflict with morality. Furthermore, the moral interpretation of the novel (at least Nabokov's works) is likely to be based on an anti-literary viewpoint. It should be said that this is a very strong assertion. Another expression of this view is that morality and literature are external to each other, and literature is fundamentally independent of morality, but related to "style". In a nutshell, style is beauty, and it has nothing to do with morality. Although the story described in the novel is an inexorable relationship between an adult man and a heterosexual underage girl. It can be said that it is "paedophilia" as far as ethics and sociology are concerned, whether it is in the real society of the United States or in the real society of different countries, and from the perspective of ethics, these are the greatest boldness. The most real depiction of human nature and aesthetics are indisputable as far as literature and art are concerned. But as far as social ethical reality is concerned, social groups under secular culture cannot accept such a relationship which is contrary to ethics and is suspected of being criminal. The emotion advocated in Lolita is a case-by-case interpretation of human feelings and human lust from the development of human nature and objective society. Such an interpretation is like revealing a secret hidden in human nature, and it is the same ethical idea of humanity that is hidden in the depths of human nature and is not revealed by society. It' s just that the author highlights what is real and not accepted by society. From this point of view, ethics has social conventions and social generality, and what is true may not be completely negated. Through the expression of the novel and its adapted film contents, there is an internal conflict between authenticity and ethics. The real things may not be accepted by ethics, but the things accepted by ethics sometimes may not be the true truth. On the screen of the movie version, there is a paragraph like this: "I look at her, look at it and look at it again and again". Almost all the scenes of desire are from the point of view of the male protagonist' s eyes, greedily and admirably show us every exquisite curve and unembellished delicate behavior. Every new expression of Lolita, with a great deal of action, makes the heart beat faster for fear of being discovered the secret. This long, tormented pleasure may be more confusing than naked hand-to-hand fights. Although this is a sad film, but the scene in the film is thrilling, random screenshots can also be like a painting. Morality in human nature is an obligation, and we must give the soul a sense of beauty. Ideological is a soul of film, it is a means to explain an era or an individual worth pondering. Therefore, in Lolita, the camera and all kinds of content about desire and realistic ethics are well hidden by the natural environment, the eyes of the characters, and the same treatment as the stream of consciousness, which is hazy but shocked. Watching through the film is the struggle of human desire and the return to the real beauty. Compared with the original novel, it is easier to think of a type of empathy and compliment of love.

\section{CONCLUSION}

The film, Lolita of 1997, gives us a new and dramatic description of the conditions of men and their spiritual state after the World War II. Relevant legal regulations, the communities where human live, conventional customs and moral standards evolve as the society advances. There are close connections among people, for instance, the relationship 
between an individual and society where they live, the relationship between ethics and truth, as well as the relationship between human and self, which all have become the main issues over philosophical ideas and literary works reflecting human's life. It can be seen that in the film, a stressed relationship is getting in the way an individual and society. The film vividly shows the audience the presentation of three aspects and clearly exhibit the protagonists' living conditions and their spiritual conditions of the time, helping the audience get a deeper and clearer understanding of Nabokov humanistic concerns and main thoughts. The literary ethics offers a brand new method of analyzing the problems related to ethics and moral problems shown in the movie.

Disorder is full of the society of the time. At that time, both Humbert and Lolita do not get as enough attention and care as they should. There are few, if any, descriptions in the film to demonstrate the harmonious relationship between Lolita's mother and Lolita. Instead, the conflicts and disharmony between them often occur and most of the scenes of them end up with contradictions and displeasure. A lot of people hold the view that marriage is a holy thing and means too much. However, the marriage of Humbert is tarnished by infidelity and betrayal and flooded by hypocrisy and filthy schemes rather the true and loyal love, which represents the painful tragedy to both the individual and the whole society. Humbert is strongly and profoundly influenced by his father's chaotic sexual relationship with different women and immoral conducts. In the final episode of the film, Lolita is going to give birth regardless the fact that she is living such a miserable life and has gone through all of those unfortunate things, which reflects the humanistic ideas of the film and makes the audience be sure that she will definitely be a nice mom. On the part of the correlation between human and society, the end of the film gives a beautiful and warm description.

It is relatively complex and sophisticated to do an analysis of the relationship between an individual and self. The climax of the film is highlighted by Humbert's act of chasing after Lolita and what he has confessed as well as his achieving his aspiration. Humbert spends all of his time of life in searching for his illusionary sexy girl, who plays the role of his spiritual dependence. Humbert's love for Lolita has gone through a shift from sexual desire to pure love. His miserable destiny is doomed due to neither his failure to get Lolita nor his shooting Quilty. All of his fate is determined by his weakness, awakening, and admittance of the fact that he indeed ruins the life of Lolita.

The perspective of literary ethics, the relatively new perspective, serves as the most significant role in analyzing and interpreting the film. But there are still a lot to analyze about the film as the paper has not done a comprehensive analysis on every front and some drawbacks exist in the paper. In conclusion, this paper analyzes the film Lolita from these three respects: the relationship between human beings and society, the relationship between human beings and self as well as the relationship between ethics and truth, providing a new perspective for the research of the film and the main thought of the original writer.

\section{REFERENCES}

[1] Davis T F, Womack K. (1998). Introduction: Reading Literature and the Ethics of Criticism. Style, (32): 184-193.

[2] John Schad. (1992). Getting it Right: Language, Literature and Ethics. Criticism, (58): 155-160.

[3] Li Dingqing. (2006). Literary Ethics Criticism and Human Spirit Construction. Foreign Literature Studies, (28): 44-52.

[4] Liu Jie. (2012). The Adaptation From the novel to the Film. Film Literature, (569):66-67.

[5] Nie Zhenzhao. (2010). Literary Ethical Criticism: Basic Theories and Terms. Foreign Literature Studies, (1): 12-22.

[6] Nie Zhenzhao. (2011). Literary Ethical Criticism: Ethical Selection and Skeffens Factor. Foreign Literature Studies, (6): 5-9.

[7] Nie Zhenzhao. (2004). Literary Ethical Criticism: Literary Criticism Methods Exploration. Foreign Literature Studies, (5): $19-20$.

[8] Nussbaum M C. (1990). Love's Knowledge: Essays on Philosophy and Literature. Journal of Philosophy, (91): 105-109.

[9] Richard A Posner. (1998). Against Ethical Criticism: PartTwo. Philosophy and Literature, (22): 395-403.

[10] Romane Clark. (1980). Philosophical Subjects: Essays Presented to P. F. Strawson. by Zak van Stratten. Ethics, (17): 694-701.

[11] Wang Jianping. (2006). The Abnormal Love Beyond Moral Boundaries--Tragic Analysis in Lolita. Journal of Social Science of Hunan Normal University, (35): 101-104.

[12] Wang Zhuo. (2015). The Ethical Dimension of “Abnormal Love"--From the Perspective of Ethical Contradiction in Lolita. Shandong Foreign Languages Teaching Journal, (36): 69-79.

[13] Wayne C. Booth. (1988). The Company We Keep: An Ethics of Fiction. Berkeley, Los Angeles, London: U of California (14): $8-12$.

Zhaodong Zeng was born in Xinzhou, Shanxi province of China in 1995. He received his bachelor degree in English Teaching from Xinzhou Teachers University, China in 2017.

He is currently a graduate in the School of Foreign Languages, Shanxi Normal University, Linfen, China. His research interests include foreign linguistics and applied linguistics. 